Taxonomy and systematics

\title{
Three new species of Agastoschizomus (Arachnida: Schizomida: Protoschizomidae) from North America
}

\section{Tres especies nuevas de Agastoschizomus (Arachnida: Schizomida: Protoschizomidae) de Norteamérica}

\author{
Rodrigo Monjaraz-Ruedas ${ }^{\mathrm{a}, \mathrm{b}, *}$, Oscar F. Francke ${ }^{\mathrm{b}}$, James C. Cokendolpher ${ }^{\mathrm{c}}$ \\ ${ }^{a}$ Posgrado en Ciencias Biológicas, Universidad Nacional Autónoma de México, Av. Universidad 3000, \\ 04510 Ciudad de México, Mexico

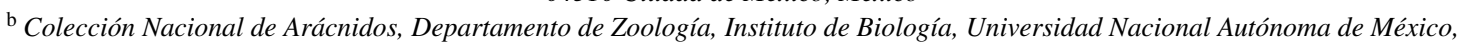 \\ 3er. Circuito exterior s/n., Apartado postal 70-153, 04510 Ciudad de México, Mexico \\ ${ }^{\mathrm{c}}$ Natural Science Research Laboratory, Museum of Texas Tech University, 2500 Broadway, \\ Lubbock, TX 79409, USA
}

Received 12 October 2015; accepted 18 February 2016

Available online 24 May 2016

\begin{abstract}
The family Protoschizomidae is currently known from 13 species and 2 genera found in Mexico. The present contribution describes 3 new species of Agastoschizomus, 2 from caves in Tamaulipas and Estado de México; the third one from a cave in Texas, USA. With this contribution, the genus Agastoschizomus attains the same richness as Protoschizomus (8 species) and the family distribution expands to include the USA. An identification key for the species in the genus is included.

All Rights Reserved (C) 2016 Universidad Nacional Autónoma de México, Instituto de Biología. This is an open access item distributed under the Creative Commons CC License BY-NC-ND 4.0.
\end{abstract}

Keywords: Micro-whip scorpions; Taxonomy; Troglomorphism; Distribution

\section{Resumen}

La familia Protoschizomidae está compuesta actualmente por 13 especies incluidas en 2 géneros, distribuidas en México. El presente trabajo aborda la descripción de 3 especies nuevas de Agastoschizomus, 2 provenientes de cuevas en Tamaulipas y el Estado de México; la tercera especie proveniente de una cueva en Texas, Estados Unidos de América. Con la presente contribución, el género Agastoschizomus alcanza la misma riqueza que el género Protoschizomus (8 especies) y la distribución de la familia se expande para incluir a los Estados Unidos de América. Se proporciona una clave de identificación para las especies del género.

Derechos Reservados (C) 2016 Universidad Nacional Autónoma de México, Instituto de Biología. Este es un artículo de acceso abierto distribuido bajo los términos de la Licencia Creative Commons CC BY-NC-ND 4.0.

Palabras clave: Microescorpiones látigo; Taxonomía; Troglomorfismo; Distribución

\footnotetext{
* Corresponding author.

E-mail address: roy_monrue@ hotmail.com (R. Monjaraz-Ruedas).

Peer Review under the responsibility of Universidad Nacional Autónoma de México.
}

\section{Introduction}

The family Protoschizomidae Rowland, 1975 is endemic to Mexico and is currently known by 13 species divided into 2 genera, Protoschizomus Rowland, 1975 with 8 species and Agastoschizomus Rowland, 1971 with 5 species (Cokendolpher \& Reddell, 1992; Monjaraz-Ruedas, 2013). Agastoschizomus is characterized primarily by the larger body size $(7-12.40 \mathrm{~mm})$, 
presence of 1 seta on the anterior process of the propeltidium, the male flagellum not enlarged distally with or without retractable ventral lobes, and the fact that species are distributed in caves and present some morphological adaptations to this environment (Cokendolpher \& Reddell, 1992; Montaño-Moreno \& Francke, 2009).

The distribution of Agastoschizomus goes from northern Mexico in the state of Tamaulipas (1 species) south along the Sierra Madre Oriental to San Luis Potosí (2 species) and Hidalgo (1 species) and then jumps westward along the Transmexican Volcanic Belt to Guerrero (Cokendolpher \& Reddell, 1992; Montaño-Moreno \& Francke, 2009; Reddell \& Cokendolpher, 1995). We describe herein 3 new species of Agastoschizomus: 1 from a cave in southern Tamaulipas; the second is from a cave in Valle de Bravo, Estado de México, and closes the geographical gap between Hidalgo and Guerrero; and the third one is from a cave in southern Texas, representing the first record of the genus and family in the U.S.A., expanding the known distribution northward by approximately $635 \mathrm{~km}$.

\section{Materials and methods}

The specimens were collected manually and preserved in $80 \%$ ethanol, and then were examined and measured with a Nikon SMZ745 stereo microscope fitted with an ocular micrometer at $20 \times$. The measurements are given in $\mathrm{mm}$. General nomenclature follows Reddell and Cokendolpher (1995); chelicerae setae nomenclature follows Lawrence (1969); flagellar setae nomenclature follows Cokendolpher and Reddell (1992), as modified by Harvey (1992); and pedipalp setae nomenclature follows Monjaraz-Ruedas and Francke (2015). Female spermathecae were dissected in $80 \%$ ethanol and cleared in lactophenol for $10 \mathrm{~min}$ (Krantz \& Walter, 2009); then they were fixed in saline solution and mounted in a semi-permanent preparation (Hoyer's medium) and examined with a compound microscope Nikon Eclipse E100. Male chelicerae were dissected in ethanol and observed in a semi-permanent preparation (Hoyer's medium). Male flagellum and palps were suspended in $96 \%$ gel alcohol and covered with a thin layer of liquid ethanol (80\%) to minimize light diffraction during photography. Photographs were taken with a Nikon Coolpix S10 VR camera with a microscope adapter and edited with Adobe Photoshop CS5. The distribution map was made with the online program ArcGIS and edited with Photoshop CS5. Specimens are deposited in the Colección Nacional de Arácnidos (CNAN), Instituto de Biología, Universidad Nacional Autónoma de México, and The Museum of Texas Tech University.
The following comparative material was examined (AMNH = American Museum of Natural History, New York; CNAN = Colección Nacional de Arácnidos, Mexico City; and TMM = The Texas Natural History Collections (formerly Texas Memorial Museum), Austin):

Agastoschizomus huitzmolotitlensis Rowland, 1975. Mexico: San Luis Potosí: Xilitla, Sótano de Huitzmolotitla, 1 km ESE of Tlamaya (=2 km NNW Xilitla) $\left[21.408320^{\circ} \mathrm{N}, 99.0018^{\circ} \mathrm{W}\right.$. $600 \mathrm{~m}$; depth in the cave where it was collected is unknown], 24 January 1964, T. Raines, T. Phillips, male holotype (AMNH). Agastoschizomus juxtlahuacensis Montaño-Moreno and Francke, 2009. Mexico: Guerrero, Quechultenango, Grutas de Juxtlahuaca $\left[17.4387333^{\circ} \mathrm{N}, 99.1595^{\circ} \mathrm{W}, 938 \mathrm{~m}\right.$ ?], 5 April 2007, H. Montaño, O. Francke, A. Valdez, C. Santibáñez, male holotype (CNAN-T0245), 1 adult male paratype (CNAN-T0246), 1 juvenile female paratype (CNAN-T0249). Agastoschizomus lucifer Rowland, 1971. Mexico: San Luis Potosí: Ciudad Valles, Sótano de la Tinaja, $10 \mathrm{~km}$ NNE of Ciudad Valles $\left[22.07597^{\circ} \mathrm{N}, 98.9778^{\circ} \mathrm{W}, 165.5 \mathrm{~m}\right], 9$ April 1966, J. Fish, D. McKenzie, male holotype, female paratype, 1 immature (AMNH).

Agastoschizomus patei Cokendolpher and Reddell, 1992. Mexico: Tamaulipas: Mainero, Cueva de la Llorona, $3.5 \mathrm{~km}$ SSE Yerbabuena $\left[24.4832^{\circ} \mathrm{N}, 99.599733^{\circ} \mathrm{W}, 1860 \mathrm{~m}\right], 12-17$ October 1986, P. Sprouse, male holotype (AMNH).

Agastoschizomus stygius Cokendolpher and Reddell, 1992. Mexico: Hidalgo: Jacala, Sótano Hondo de Pinalito, Pinalito (a village located at kilometer post 105 on highway 85 north of Jacala) [21.01611 ${ }^{\circ} \mathrm{N}, 99.164765^{\circ} \mathrm{W}, 1600 \mathrm{~m}$ ], 1 January 1976, C. Soileau, P. Strickland, female holotype (AMNH).

Protoschizomus franckei Monjaraz-Ruedas, 2013. Mexico: Guerrero: Taxco de Alarcón, Cueva de Boca del Diablo, Acuitlapán [18.59916 ${ }^{\circ} \mathrm{N}, 99.54579^{\circ} \mathrm{W}, 1594$ m], 21 April 2012, G. Contreras, J. Mendoza, R. Monjaraz, D. Ortiz, male holotype (CNAN-T0384), female paratype (CNAN-T0385).

Protoschizomus occidentalis Rowland, 1975. MEXICO: Colima: $20.9 \mathrm{~km}$ SW Colima $\left[19.113469^{\circ} \mathrm{N}, 103.8571^{\circ} \mathrm{W}\right.$, $202 \mathrm{~m}], 16$ July 1972, A. Jung, male holotype (AMNH).

Protoschizomus purificacion Cokendolpher and Reddell, 1992. Mexico: Tamaulipas: Hidalgo, Cueva X, Conrado Castillo [23.96311 $\left.{ }^{\circ} \mathrm{N}, 99.47554^{\circ} \mathrm{W}, 1950 \mathrm{~m}\right], 27$ December 1986, P. Sprouse, female holotype (AMNH); 15 April 1980, D. Pate, immature male paratype (TMM). 
Identification key for the species of Agastoschizomus.

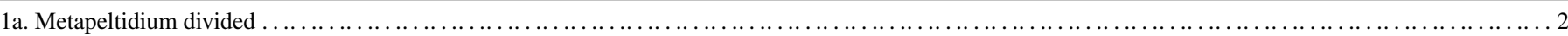

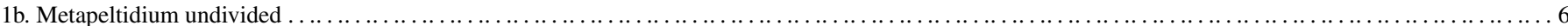

2a. Male flagellum with ventrolateral lobes; anterior sternum with 2 sternopophysial setae; female flagellum with annuli; spermathecal lobes long and

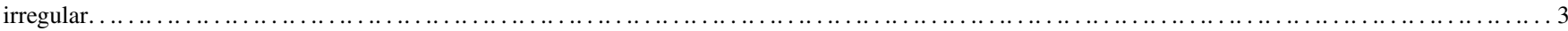

2b. Male flagellum without ventrolateral lobes; anterior sternum with 1 sternopophysial seta; female flagellum without annuli; spermathecal lobes short and

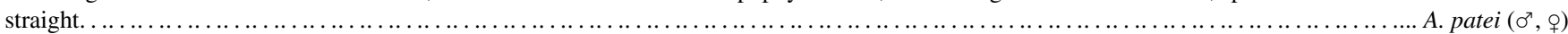

3a. Male flagellum lanceolate; pedipalp trochanter without projections; spermathecal lobes asymmetric and slender along their length................... 4

3b. Male flagellum roughly tubular and wide; pedipalp trochanter with a slight projection (apical process); spermathecal lobes symmetrical and

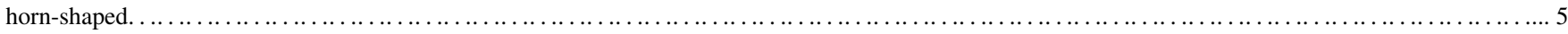

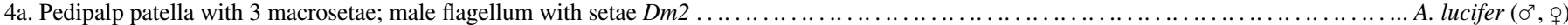

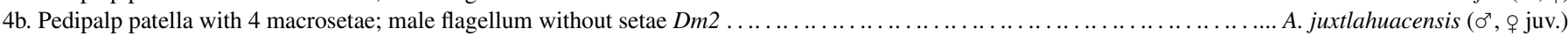

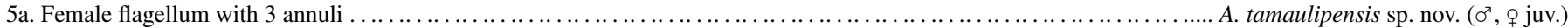

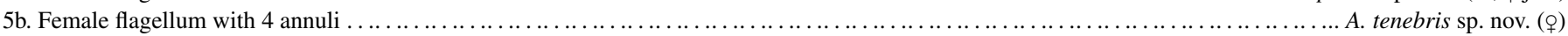

6a. Femur IV less than 4.8 times longer than wide; female flagellum with 4 annuli; abdominal tergite I with large posterior setae $\ldots \ldots \ldots \ldots \ldots \ldots \ldots \ldots \ldots .7$

6b. Femur IV 6.0 times longer than wide; female flagellum with 2 annuli; abdominal tergite I without large posterior setae ........................ stygius (o)

7a. Pedipalp patella with 2 macrosetae; pedipalp tibia with 4 macrosetae; adult body size large $(7 \mathrm{~mm})$; setae Dm3 present ............. A. huitzmolotitlensis ( $\left.0^{7}\right)$

7b. Pedipalp patella with 3 macrosetae, pedipalp tibia with 5 macrosetae; adult body size small $(3.28 \mathrm{~mm})$; setae $D m 3$ absent ......A. texanus sp. nov. (ơ juv, o)

\section{Description}

\section{A. tamaulipensis sp. nov. Figures 1-8}

\section{Diagnosis}

Males can be distinguished by the tubular shape of the flagellum, ending in a triangular projection (Figs. 3-5), with 3 extra setae on dorsal surface; by the presence of a slight projection (apical process) on pedipalp trochanter (Figs. 6 and 7), and the presence of 4 sclerotized setae on the mesolateral surface of the pedipalp tibia. A. tamaulipensis resembles A. lucifer and A. juxtlahuacensis in having a divided metapeltidium (undivided in other species in the genus), but differs from the last 2 in the general shape of the flagellum which is roughly tubular and wider in A. tamaulipensis, and it is conical and slender in A. lucifer and A. juxtlahuacensis; also A. tamaulipensis has seta Dm2 on male flagellum as in A. lucifer, but it is absent in A. juxtlahuacensis; finally, adult A. lucifer are larger (8.14) than A. tamaulipensis (6.40). The other species recorded from Tamaulipas is $A$. patei from which the new species differs in that the male of $A$. patei lacks ventrolateral lobes on male flagellum,

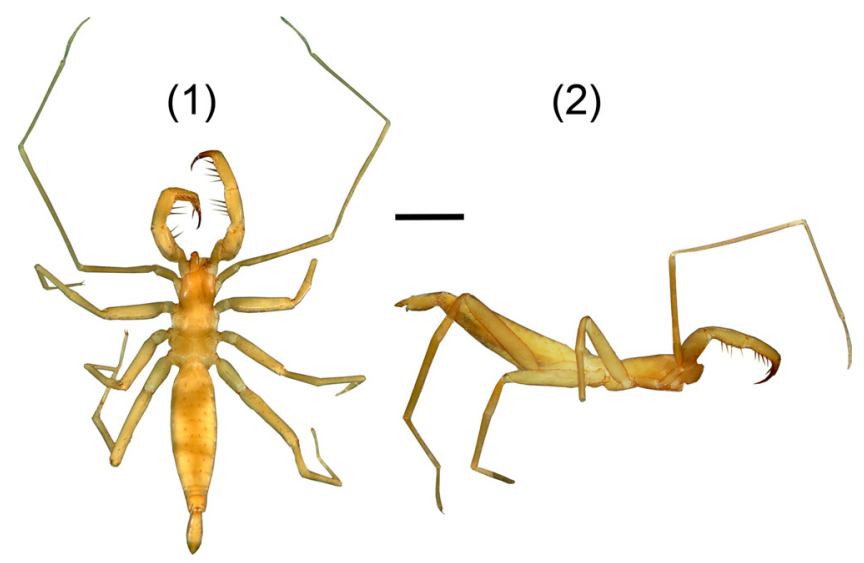

Figures 1-2. Agastoschizomus tamaulipensis sp. nov. Male holotype. Habitus: 1 , dorsal view; 2 , lateral view. Scale bar $=2 \mathrm{~mm}$. has the metapeltidium undivided, and females lack any annuli or flagellomeres on the flagellum.

\section{Description}

Male (holotype). Pale brownish yellow. Length from anterior margin of propeltidium to base of flagellum 6.40, flagellum 1.41 long (Figs. 1 and 2). Prosoma: propeltidium 2.27 long, 1.20 wide; anterior process slightly curved downward; with 1 seta on anterior process and 1 pair setae at base of process; with 2 pairs of dorsal setae, the first pair longer than second pair; without ocular spots. Mesopeltidial plates 0.56 long; gap between the plates 0.11 . Metapeltidium divided, each plate 0.37 wide. Anterior sternum with 7 setae, plus 2 sternapophysial setae; posterior sternum with 4 setae.

Chelicerae (Fig. 8). Serrula with 8 teeth. Setae $1=3,2=6$, $3=11,4=2,5=0,6=1$.

Pedipalps (Figs. 6 and 7). Trochanter slightly produced distally, with a small protuberance on distal margin (apical process); with scattered long setae on ventral margin; with a row of 6 setae on mesoventral margin, plus 1 pair of setae on mesal surface near upper margin; without mesal spur. Femur, ectal surface with 4 long macrosetae near ventral margin, plus 2 setae on dorsal margin; mesal surface with 8 macrosetae. Patella ventrally with 2 rows of spiniform setae; mesal row with 5 macrosetae, ectal row with 3 spiniform setae, basal shortest and distal longest. Tibia with 3 ventrolateral rows of spiniform setae, 2 mesal and 1 ectal, external mesal row with 6 setae, medial mesal row with 4 setae, ectal row with 6 setae (Fig. 8). Basitarsus-tarsus with 2 symmetrical spurs 0.29 long; claw 0.56 long.

Legs. Leg I, including coxa, 13.08 long; basitarsal-telotarsal proportions: 28:8:8:8:8:6:15. Femur IV 5.5 times longer than deep.

Opisthosoma. Tergite I with 2 pairs of anterior microsetae (in row) and 2 large posterior setae; tergite II with 6 anterior 
(3)
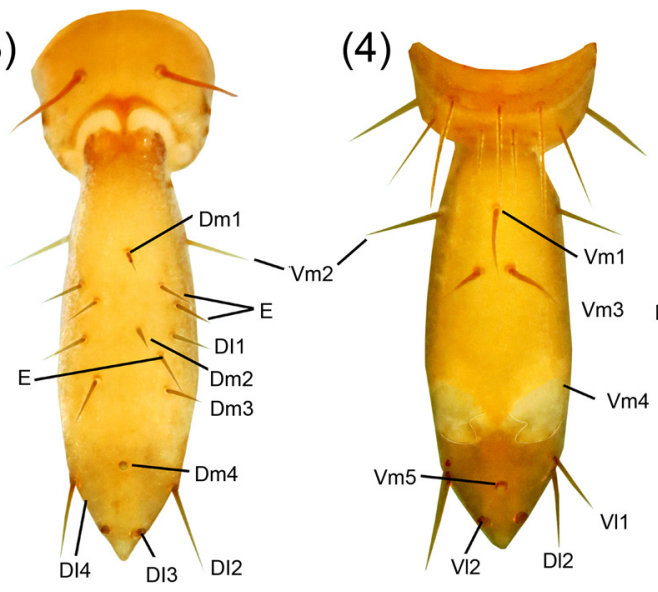

(5)

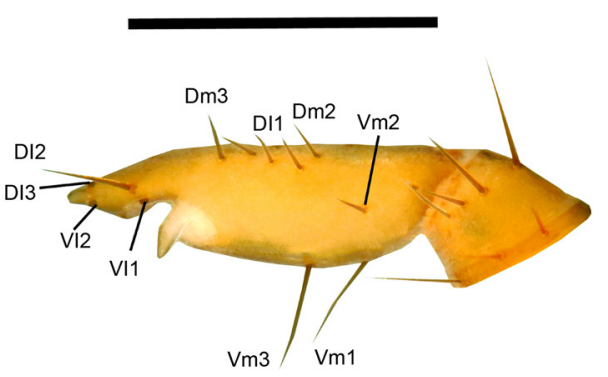

(6)

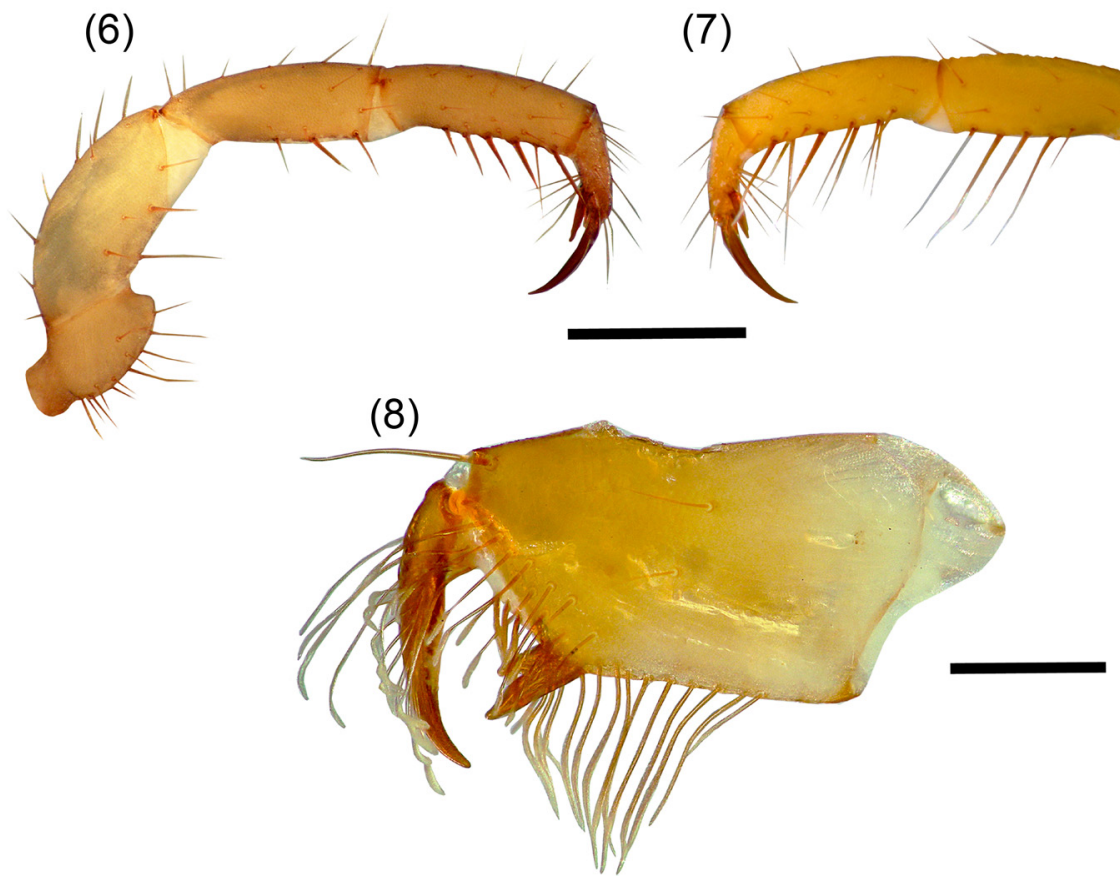

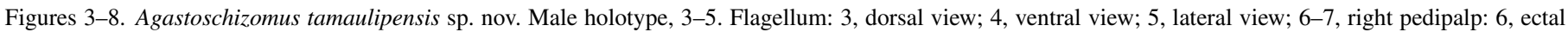
view, 7, mesal view; 8, right chelicera, mesal view. E, extra setae. Scale bars $=1 \mathrm{~mm}(3-7), 0.2 \mathrm{~mm}(8)$.

microsetae (paired) and 2 large posterior setae; tergites III-V with 2 dorsal setae; tergites VI, VII with 2 dorsal and 2 dorsolateral setae each; tergites VIII-IX with 2 dorsal setae and 4 dorsolateral setae; segments X-XII cylindrical, semitelescopic, segments X, XI with 4 lateral and 2 ventral setae, segment XII with 2 dorsal, 4 lateral and 6 ventral setae; without posterodorsal process. Sternites II, III with scattered setae, sternites IV-IX with 2 irregular rows of setae near posterior margin. Genital plate distinctly sclerotized. Sternite VI 2.94 times longer than wide; width/length ratio versus body length 2.18 . Flagellum (Figs. 3-5) 1.41 long, 0.45 wide; tubular, expanded medially, with a pair of long submedian ventrolateral lobes; seta Dm2 present; with 3 extra setae on dorsal surface, presumably the anterior pair corresponds to the pair of microsetae present on some species of Protoschizomus such as P. occidentalis Rowland, 1975, and P. franckei Monjaraz-Ruedas, 2013, and also present in some species of Hubbardiidae (microsetae in males of Monjaraz-Ruedas \& Francke, 2015).
Subadult female (paratype). Despite having annuli separating the flagellomeres, the small size and lack of sclerotized genitalia suggest that this is a penultimate instar female. Length from anterior margin of propeltidium to base of flagellum, 4.40. Propeltidium 1.44 long, 0.70 wide; setation as on male; sternite VI 3.60 times longer than wide; width/length ratio versus body length, 1.22. Flagellum, 0.54 long; Dm2 setae absent; with 3 annuli separating 4 flagellomeres. Spermathecae not sclerotized (could not be observed even though the genital plate was dissected, cleared and mounted on a slide). Chelicera: serrula with 8 teeth. Setae $1=3,2=6,3=8,4=2,5=0,6=1$. Leg I, including coxa, 6.94 long; basitarsal-tarsal proportions 20:6:6:6:6:6:21. Femur IV 5.6 times longer than deep.

Variation. The subadult female pedipalp patella has 2 rows of spiniform setae; mesal row with 3 macrosetae, ectal row with 2 macrosetae. Tibia with 3 ventrolateral rows of spiniform setae, 2 mesal and 1 ectal, external mesal row with 5 setae, medial 


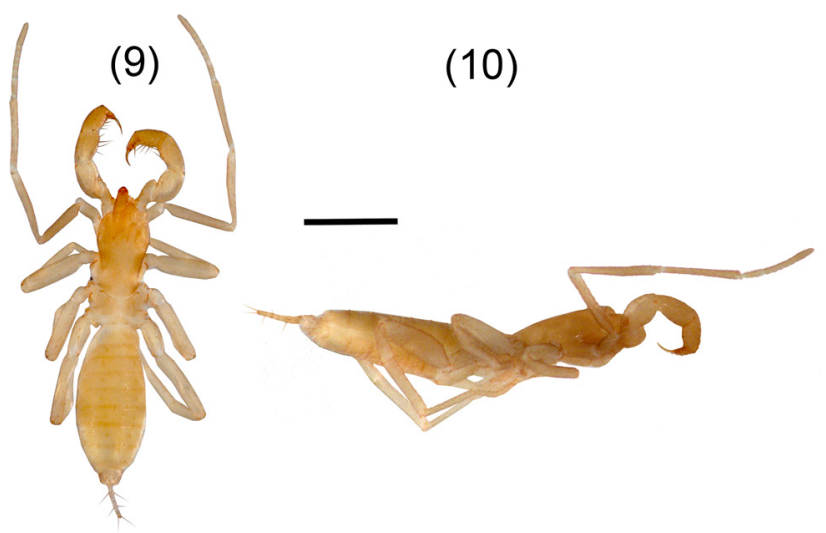

Figures 9-10. Agastoschizomus texanus sp. nov. Female holotype. Habitus: 9, dorsal view; 10 , lateral view. Scale bar $=1 \mathrm{~mm}$.

mesal row with 2 setae, ectal row with 4 setae. Cheliceral setation: G3 varies, with 11 on male and 8 on female.

Measurements ( $\mathrm{mm}$ ). Male holotype (subadult female paratype): Pedipalp: trochanter $0.83(0.48)$; femur $1.36(0.75)$; patella 1.28 (0.64); tibia $1.20 \quad(0.61)$; basitarsus-tarsus 0.61 (0.35); total 5.28 (2.83). Leg I: coxa $0.80(0.42)$; trochanter 0.86 (0.48); femur 3.32 (1.63); patella 3.64 (1.81); tibia 2.84 (1.47); basitarsus 0.56 (0.32); tarsus 1.06 (0.82); total 13.08 (6.94). Leg IV: trochanter 1.14 (0.59); femur 2.88 (1.65); patella $1.48(0.80)$; tibia $2.44(1.23)$; basitarsus $1.60(0.88)$; tarsus 1.00 (0.77); total 10.54 (5.93).

\section{Taxonomic summary}

Type material. Mexico: Tamaulipas: holotype adult male, Municipio Ciudad Mante, Grutas de Quintero, $1.5 \mathrm{~km} \mathrm{~S}$ of Quintero (22.6499333 ${ }^{\circ}$ N, 99.041155 $\left.{ }^{\circ} \mathrm{W}, 452 \mathrm{~m}\right), 27$ November 2004, E. Fant, J. Fant (CNAN-T0983). Paratype: 1 subadult female (CNAN-T0984), 28 November 2004, same data as holotype.

Etymology. The specific name refers to the state where the specimens were collected.

Distribution. Known only from the type locality (Fig. 27).

Natural history. The cave is located about $2 \mathrm{~km}$ from the town of Quintero; it is a touristic cave open to the public. The cave is about $500 \mathrm{~m}$ long and it is completely horizontal, there is a skylight about $70 \mathrm{~m}$ from the entrance. It is highly disturbed and there are many graffiti on the walls.

\section{A. texanus sp. nov. Figures 9-17}

\section{Diagnosis}

Females present the metapeltidium undivided (Fig. 9), although the most important characteristic which differs dramatically from congeners is that it is the smallest known species $(3.28 \mathrm{~mm})$, approximately half the size of other adult females. Adult male remains unknown. Also distinguished by the presence of spermathecae (Fig. 16) with a pair of lobes long and curved at the tip (inverse $\mathrm{J}$ shaped) and by the absence of the setae Dm3 pair. A. texanus resembles A. patei, A. stygius and A. huitzmolotitlensis in having the metapeltidium undivided; A. texanus differs from $A$. patei and A. stygius in having 4 annuli on the flagellum, whereas $A$. patei does not have annuli, and $A$. stygius has only 2 annuli. A. texanus resembles A. lucifer in the shape of the flagellum and by having the same number of annuli (4) but differs from A. lucifer in the absence of setae $D m 3$ and in the metapeltidium being divided in A. lucifer. Also, A. texanus differs from A. huitzmolotitlensis and $A$. stygius by having a relatively shorter femur IV, 3.35 times longer than wide, versus 4.8 and 6 times, respectively. Also, differs by the spermathecae with long and curved lobes, whereas A. stygius and A. patei present short and straight spermathecal lobes. Finally, differs from A. stygius in having 1 pair of large setae on tergite I, whereas A. stygius has none.

\section{Description}

Female (holotype). Pale yellowish-brown. Length from anterior margin of propeltidium to base of flagellum 3.28, flagellum 0.35 long (Figs. 9 and 10). Prosoma: Propeltidium 1.14 long, 0.58 wide; anterior process curved downward; with 1 seta on anterior process and 1 pair setae at base of process; with 2 pairs of dorsal setae, the first pair longer than second pair and near lateral margin; without ocular spots. Mesopeltidial plates 0.24 long; gap between the plates 0.06. Metapeltidium undivided, 0.64 wide, 0.29 long. Anterior sternum with 9 setae, plus 2 sternapophysial setae; posterior sternum with 4 setae.

Chelicera (Fig. 17). Serrula with 9 teeth. Setae $1=3,2=6$, $3=13,4=3,5=0,6=1$.

Pedipalps (Figs. 14 and 15). Trochanter not produced distally; with scattered setae on ventral margin, plus 6 setae on ectal face; with a row of 6 setae on mesoventral margin plus 2 pairs of setae on mesal surface near upper margin; without mesal spur. Femur, ectal surface with 6 setae near ventral margin, plus 3 setae on dorsal margin; mesal surface with 9 macrosetae. Patella ventrally with 2 rows of spiniform setae; mesal row with 4 macrosetae of same length, ectal row with 3 macrosetae, basal shortest and distal longest. Tibia with 3 ventrolateral rows of spiniform setae, 2 mesal and 1 ectal, external mesal row with 5 setae, medial mesal row with 4 setae, ectal row with 5 spiniform setae (Fig. 15). Basitarsus-tarsus with 2 symmetrical spurs 0.21 long; claw 0.08 long.

Legs. Leg I, including coxa, 4.18 long; basitarsal-telotarsal proportions: 15:4:4:4:4:4:16. Femur IV 3.35 times longer than deep.

Opisthosoma. Tergite I with 2 pairs of anterior microsetae (in row) and 2 large posterior setae; tergite II with 6 anterior microsetae (paired) and 2 large posterior setae; tergite III with 1 pair of dorsal setae, tergites IV-VI with 1 pair of dorsal setae, plus 1 pair of dorsolateral setae; tergite VII with 1 pair of dorsal and 2 pairs of dorsolateral setae; tergites VIII, IX with 2 rows of setae with 1 dorsal pair and 2 dorsolateral pairs of setae each; segments X-XII cylindrical, telescopic; segments X, XI with 


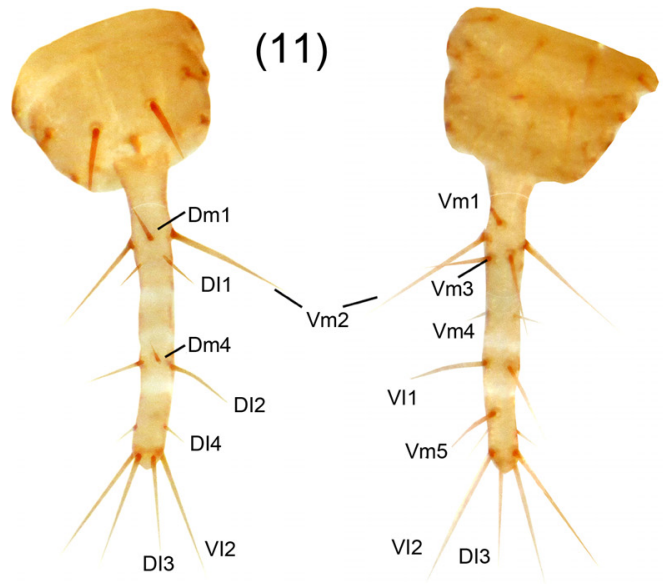

$(12)$
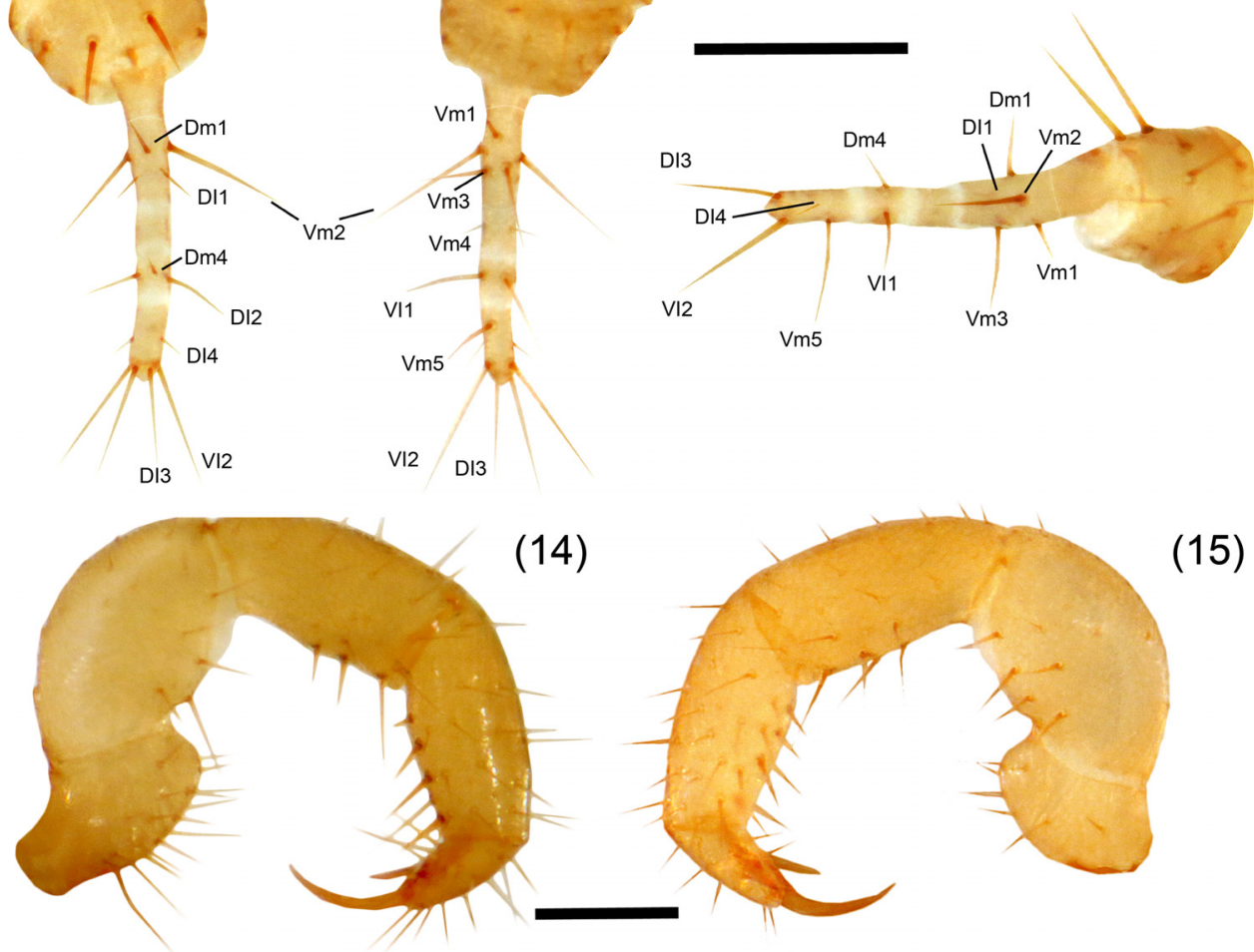

(14)

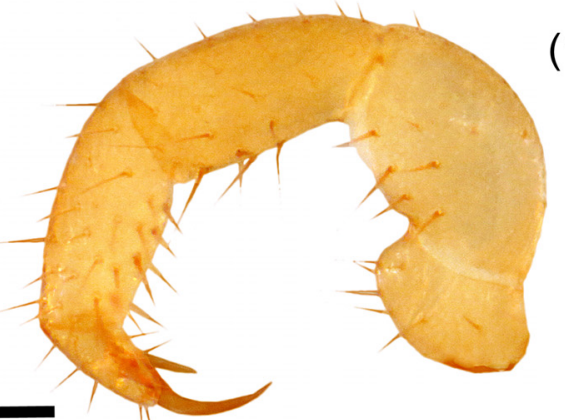

(15)

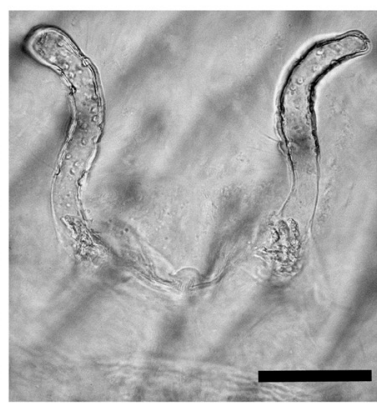

(16)

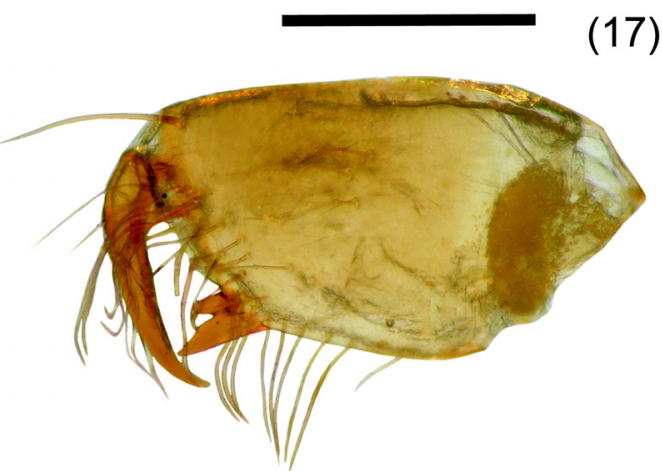

Figures 11-17. Agastoschizomus texanus sp. nov. Female holotype, 11-13. Flagellum: 11, dorsal view; 12, ventral view; 13, lateral view; 14-15, right pedipalp: 14, ectal view, 15, mesal view; 16, spermathecae, dorsal view; 17, right chelicera, mesal view. Scale bars $=0.2 \mathrm{~mm}(11-15,17), 0.05 \mathrm{~mm}(16)$.

3 pairs of ventral setae and 1 pair of lateral setae, segment XII with 1 pair of dorsal setae, 1 pair of lateral setae and 2 pairs of ventral setae; without posterodorsal process. Sternites II, III with scattered setae; sternites IV-IX with 2 well defined rows of setae. Genital plate distinctly sclerotized. Sternite VI 4.6 times longer than wide; width/length ratio versus body length, 0.71 . Flagellum (Figs. 11-13) 0.35 long, 0.05 wide; setae $D m 2$ and $D m 3$ absent; with only 4 annuli separating 4 flagellomeres. Spermathecae (Fig. 16) with 1 pair of long, tubular lobes not increasing in diameter apically, joined at the base; apex of the lobes curved apically (inverse "J" shaped), with tip pointing ectally.

Male subadult paratype. The subadult male can be recognized by the presence of a deeper flagellum which differs from the female in size and shape being wider at the base than the flagellum of the female, as was indicated also for P. purificacion by Cokendolpher and Reddell (1992) (Fig. 75, p. 61). Setation as on adult female; differs from adult female in size, 2.40 body length and in shape and length of the flagellum 0.40, which is longer and deeper than female flagellum.

Variation. The 2 females and the juvenile specimens are of the same length, which indicates that the adults of $A$. texanus are smaller than the rest of species of the genus, and the diagnosis for the genus should be amended accordingly. Fixed finger of the chelicerae in 1 female presents very reduced teeth (wear?). Setation pattern as in the holotype.

Measurements ( $\mathrm{mm}$ ). Female holotype (subadult male paratype): Pedipalp: trochanter 0.30 (0.24); femur 0.50 (0.43); patella $0.42(0.35)$; tibia $0.46(0.34)$; basitarsus-tarsus 0.19 (0.18); total 1.87 (1.54). Leg I: coxa 0.37 (0.30); trochanter 
0.30 (0.27); femur 0.94 (0.77); patella 0.90 (0.72); tibia 0.85 (0.66); basitarsus 0.24 (0.21); tarsus 0.58 (0.56); total 4.18 (3.49). Leg IV: trochanter $0.48(0.42)$; femur $0.91(0.75)$; patella 0.42 (0.40); tibia $0.69(0.56)$; basitarsus $0.58(0.45)$; tarsus 0.48 (0.38); total 3.55 (2.96).

\section{Taxonomic summary}

Type material. USA: Texas: holotype adult female (TTUZ_060311), Seminole Sink (=Seminole Canyon Cave), Seminole Canyon State Park, Val Verde County (415 m), 20 February 2009, P. Paquin, M. Sanders, K. O'Connor. Paratypes: 1 subadult male (TTU-Z_060312), same data as holotype. 1 female and 1 subadult female (CNAN-T1002), same locality as holotype, 29 May 2015, P. Sprouse, B. Hutchins, and A. Scott. Geographical coordinates are not provided due to the conservation status of the cave (see below), and following the recommendation of the Texas Parks and Wildlife Department.

Etymology. The specific name refers to the state where the species is found.

Distribution. Known only from the type locality (Fig. 27).

Natural history. The cave is located in a very hot and dry environment in southern Texas. It is about $7 \mathrm{~m}$ deep (narrow sinkhole) and $63 \mathrm{~m}$ long (distance), the cave is well suited for invertebrate fauna because of its small entrance, which maintains a high humidity in the cave, and the deep soil, which supports fungal growth. The variety of predators found in the cave indicates that it is a moderately rich cave ecosystem (Elliott $\&$ Reddell, 1985). Seminole Sink is an important archeological site and the original (1984) specimen was collected from the underside of a small rock deeply buried in the talus cone beneath the $7 \mathrm{~m}$ deep entrance sink (Cokendolpher \& Reddell, 1992). The 2 specimens collected in 2009 and 2 specimens collected in 2015 were found deep in the cave.

\section{Remarks}

This species was reported previously by Cokendolpher and Reddell (1992) as "undetermined genus and species" because they only had 1 juvenile, deposited at the Texas Memorial Museum, collected by W. Elliott and L. Bement in 1984; however, further attempts at that time to collect an adult male were unsuccessful, obtaining instead an apparent juvenile which resulted to be the very small adult female of this new Agastoschizomus. Recently, Peter Sprouse, Ben Hutchins and Ann Scott conducted a new expedition to the cave in May 2015 to search for the adult male; however, they only collected 2 additional female specimens, which are also very small.

\section{A. tenebris sp. nov. Figures 18-26}

\section{Diagnosis}

It can be distinguished by the peculiar shape of the spermathecae with a general "horn" shape and the lobes are constricted submedially (Fig. 25); by the presence of 4 annuli on flagellum separating 5 flagellomeres; presence of 5 setae on ectal surface

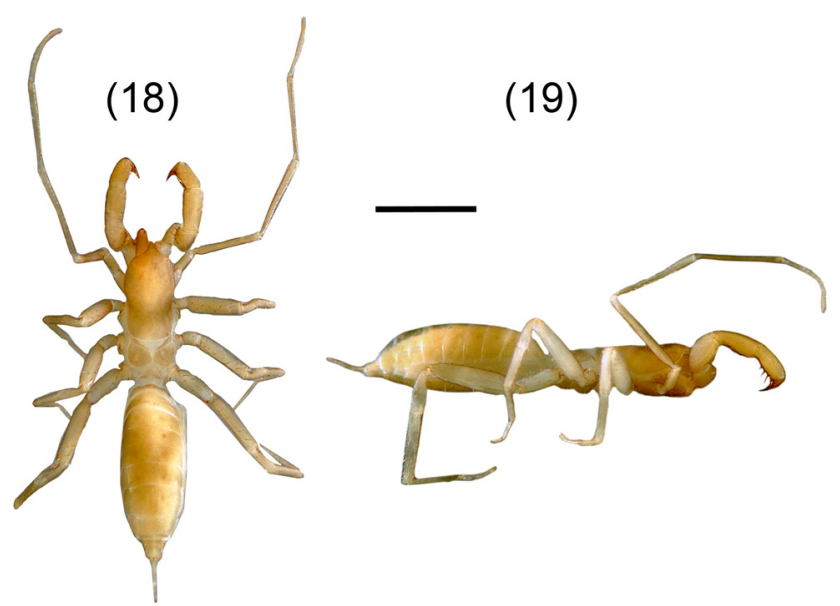

Figures 18-19. Agastoschizomus tenebris sp. nov. Female holotype. Habitus: 18 , dorsal view; 19 , lateral view. Scale $b a r=2 \mathrm{~mm}$.

of femur pedipalp, and the mesal row of the pedipalp tibia with 7 setae (Fig. 24). A. tenebris resembles A. lucifer, A. juxtlahuacensis and A. tamaulipensis having a divided metapeltidium, and resembles A. lucifer and A. juxtlahuacensis having a 4 annulated flagellum, however differs from A. tamaulipensis in the number of annuli present in the flagellum, with 3 in A. tamaulipensis and 4 in A. tenebris. Also differs from A. lucifer in the shape of the spermathecae which present 2 straight lobes, whereas in A. tenebris they are slightly curved; finally, A. lucifer is considerably larger $(12 \mathrm{~mm})$ than A. tenebris $(6 \mathrm{~mm})$. A. tenebris differs from $A$. juxtlahuacensis in the size of the pedipalps and the length of the claws (shorter than the tarsus in A. juxtlahuacensis), sharing the number of seta on pedipalp patella (4 setae). A. tenebris resembles A. texanus in the general "horned" shape of the spermathecae having lobes curved distally and joined at the base and in the number of setae on pedipalp patella (4 setae), but differs from $A$. texanus in having a divided metapeltidium, the body size ( $3.28 \mathrm{~mm}$ in A. texanus) and the number of setae on pedipalp.

\section{Description}

Female (holotype). Pale brownish-yellow. Length from anterior margin of propeltidium to base of flagellum 6.00, flagellum 0.83 long (Figs. 18, 19). Prosoma: Propeltidium 1.84 long, 0.93 wide; anterior process slightly curved downward; with 1 setae on anterior process and 1 pair setae at base of process; with 4 pairs dorsal setae, anterior 3 pairs the same length and forming 2 rows of 3 setae each, the posterior pair shorter; without ocular spots. Mesopeltidial plates 0.37 long; gap between the plates 0.08 . Metapeltidium divided, 0.43 wide, 0.45 long each plate. Anterior sternum with 11 setae, plus 2 sternapophysial setae; posterior sternum with 4 setae.

Chelicerae (Fig. 26). Serrula with 8 teeth. Setae $1=3,2=6$, $3=12,4=2,5=0,6=1$.

Pedipalps (Figs. 23, 24). Trochanter not produced distally; with scattered setae on ventral margin, with a row of 4 setae on ectal 


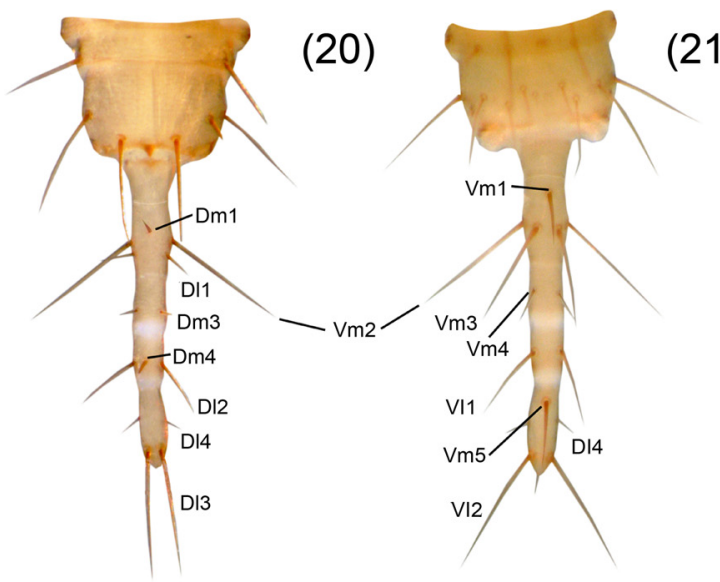

(21)

(22)

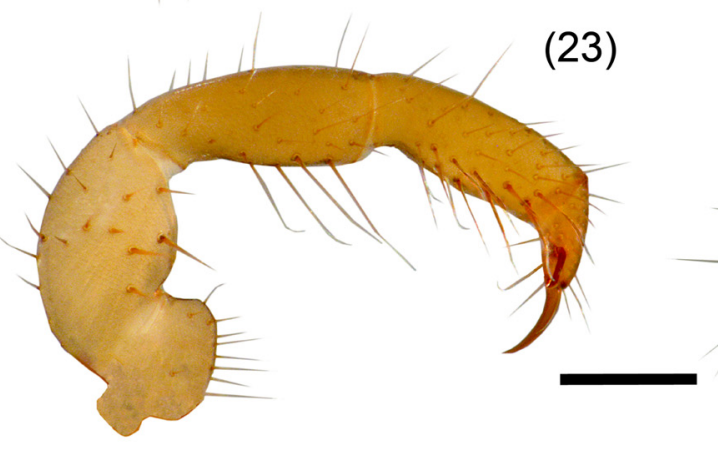

(23)

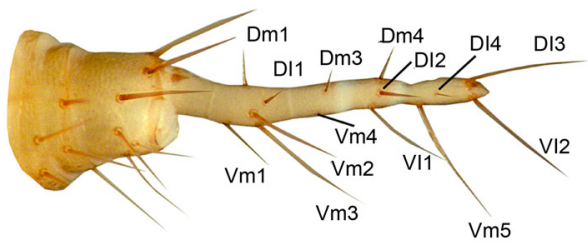

(25)

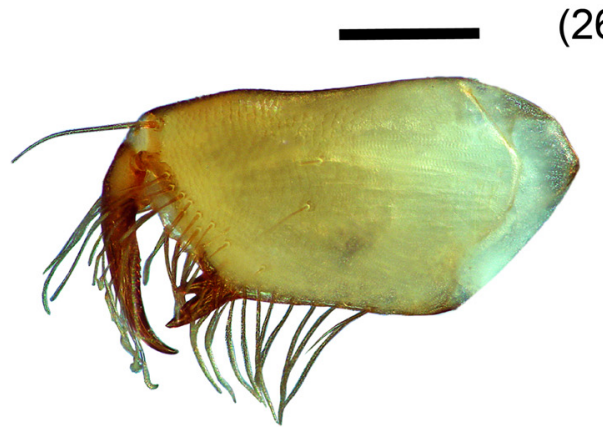

(24)

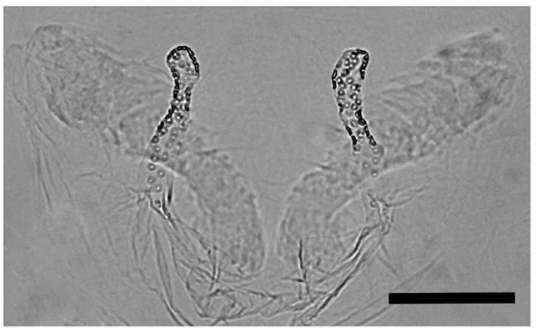

26)

Figures 20-26. Agastoschizomus tenebris sp. nov. Female holotype, 20-22. Flagellum: 20, dorsal view; 21, ventral view; 22, vateral view; 23-24, right pedipalp: 23, mesal view; 24, ectal view; 25, spermathecae, dorsal view; 26, right chelicera, mesal view. Scale bars $=0.5 \mathrm{~mm}(20-24), 0.2 \mathrm{~mm}(25), 0.05 \mathrm{~mm}(26)$.

surface, plus 2 ectal setae near dorsal margin; mesal surface with a ventral row of 6 setae, plus 2 setae on mesal surface near dorsal margin; without mesal spur. Femur with 5 setae near ventral margin on ectal surface, plus 3 setae on dorsal margin; mesal surface with 10 macrosetae. Patella ventrally with 2 rows of spiniform setae; mesal row with 4 macrosetae increasing in length distally; ectal row with 3 macrosetae, basal shortest and distal longest (Fig. 24). Tibia with 3 ventrolateral rows of spiniform setae, 2 mesal and 1 ectal, external mesal row with 7 setae, medial mesal row with 5 setae, ectal row with 5 setae (Fig. 25). Basitarsus-tarsus with 2 symmetrical spurs 0.21 long; claw 0.11 long.

Legs. Leg I, including coxa, 5.24 long; basitarsal-telotarsal proportions: 14:3:4:4:3:3:17. Femur IV 4.1 times longer than deep.

Opisthosoma. Tergite I with 2 pairs of anterior microsetae (in row) and 2 large posterior setae; tergite II with 7 anterior microsetae (in 2 rows) and 2 large posterior setae; tergite III with 1 pair of dorsal setae, tergites IV-VI with 1 pair of dorsal setae, plus 1 pair of dorsolateral setae; tergite VII with 1 pair of dorsal and 2 pairs of dorsolateral setae; tergites VIII, IX with 2 rows of setae with 1 dorsal pair and 2 dorsolateral pairs of setae each; segments X-XII cylindrical telescopic, segment X with 1 ventral pair and 2 ventrolateral pairs of setae, segment XI with 2 pairs of ventral setae and 2 pair of lateral setae, segment XII with 1 pair of dorsal setae, 3 pairs of lateral setae and 2 pairs of ventral setae; without posterodorsal process. Sternites II, III with scattered setae; sternites IV-IX with 2 well defined rows of setae. Genital plate distinctly sclerotized. Sternite VI 2.8 times longer than wide; width/length ratio versus body length, 2.2. Flagellum (Figs. 20-22) 0.83 long, 0.11 wide; setae $D m 2$ absent; with 4 annuli separating 5 flagellomeres. Spermathecae (Fig. 25) with 1 pair of long, tubular lobes not increasing in diameter apically, with a slight constriction submedially and joined at the base; apex of the lobes slightly curved apically 


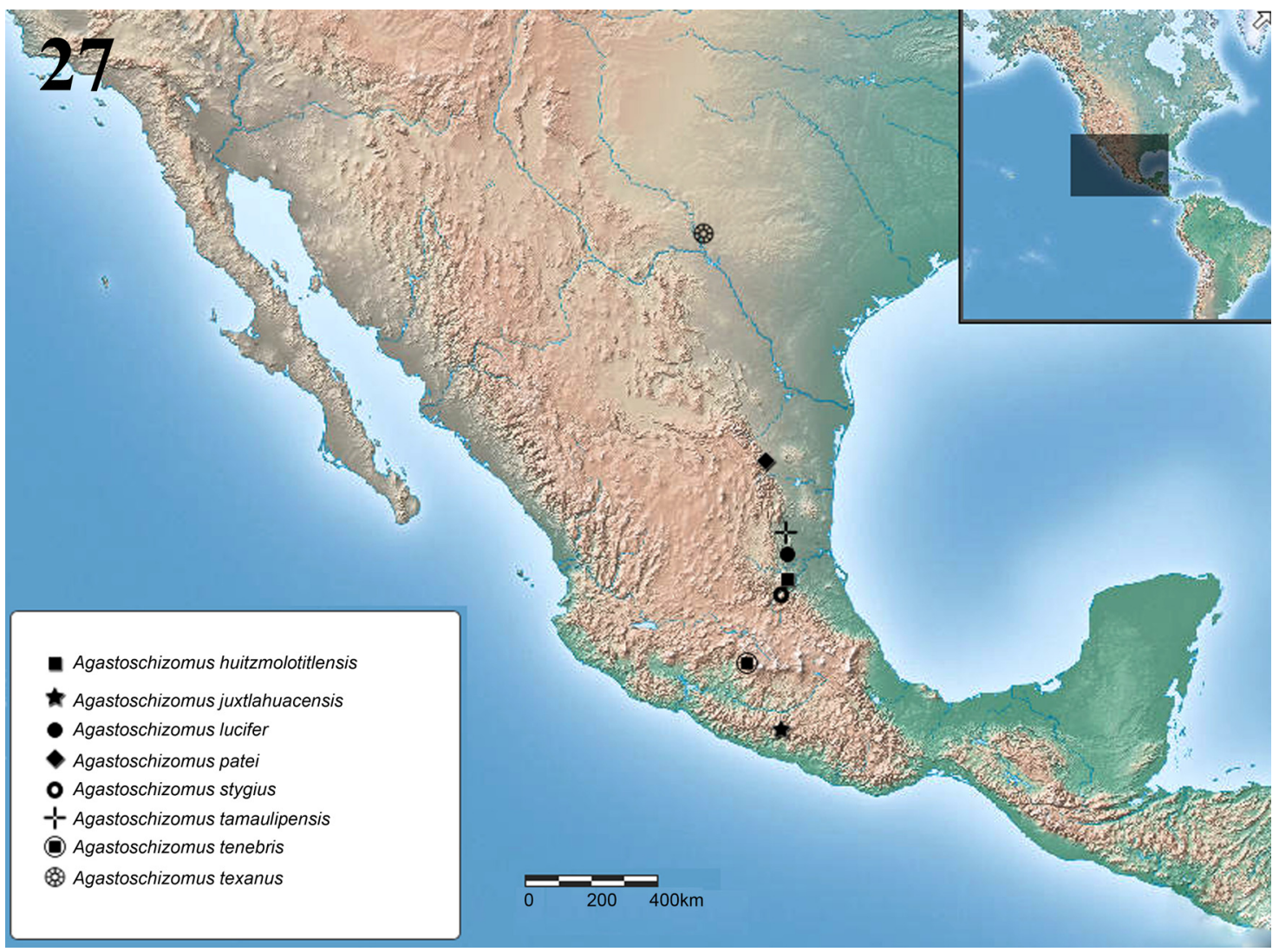

Figure 27. Distribution map of the known species of Agastoschizomus.

(horn-shaped), with tip pointing in an angle of $45^{\circ}$ ectally; with 2 sclerotized plates behind the lobes.

\section{Adult male. Unknown.}

Variation. The subadult female presents body setation as on holotype, differs from it in having only 4 setae on the pedipalp femur and 3 setae on the pedipalp patella. Cheliceral setation: G3 varies, with 12 on adult female and 9 on subadult female.

Measurements ( $\mathrm{mm}$ ). Female holotype (subadult female): Pedipalp: trochanter $0.60(0.44)$; femur $0.84(0.64)$; patella 0.76 (0.54); tibia 0.80 (0.56); basitarsus-tarsus $0.35(0.24)$; total 3.35 (2.42). Leg I: coxa $0.51(0.42)$; trochanter $0.48(0.42)$; femur 1.73 (1.12); patella $1.71(1.22)$; tibia $1.60(1.10)$; basitarsus 0.37 (0.28); tarsus 0.96 (0.68); total 7.37 (5.24). Leg IV: trochanter 0.88 (0.62); femur $1.68(1.30)$; patella $0.77(0.64)$; tibia 1.33 (0.98); basitarsus 1.17 (0.84); tarsus 0.67 (0.46); total 6.51 (4.84).

Type material. Mexico: Estado de México: holotype adult female, Cueva del Diablo, Peña de Valle de Bravo $\left(19.20069^{\circ} \mathrm{N}\right.$, $-100.14148^{\circ}$ W, 1885 m), 27 August 2011, D. Barrales, J. Mendoza, E. Miranda, R. Monjaraz, A. Valdez (CNAN-T0989). Paratype: 1 subadult female (CNAN-T0990), same data as holotype.
Etymology. The specific name means darkness in Latin, referring to the malefic aspect of the cave in which the specimens were collected. It is a cave where witchcraft rituals are performed, and the smoke of the candles provides a very gloomy aspect inside the cave.

Distribution. Known only from the type locality (Fig. 27).

Natural history. The cave is located among the crags surroundings the Valle de Bravo's lake, and it is actually located in the middle of the homonymous city. It is a small horizontal cave, about $200 \mathrm{~m}$ in length, with a high level of human disturbance as the visitors perform witchcraft rituals inside the cave. Specimens were collected under small rocks near the walls at the deepest part of the cave, in a small area with high humidity.

\section{Remarks}

The importance of this species resides on its geographical position, which connects the distribution of the entirely family from north to south in the Sierra Madre Oriental through the Transmexican Volcanic Belt in a probably restricted population inside a cave. Attempts to collect additional specimens, hoping for an adult male in June of 2015 were unsuccessful.

Conservation status. It is important to notice that caves are places very susceptible and fragile, easily disturbed, as well as 
shelter for many species found only in caves, and the majority on the invertebrate cave fauna are micro-endemics found only in a specific cave (Galán \& Herrera, 1998). However, the communities near them use the caves as landfills or to perform some kind of rituals or religious ceremonies, which has resulted in loses of the original habitats for many species that inhabit the caves, putting them at severe risk of local extinction. This is the case for the caves in which Protoschizomids are found: in the case of $A$. texanus, the cave is gated and protected from development as it lies completely within Seminole Canyon State Park and Historic Site, which is owned and managed by Texas Parks and Wildlife Department; in addition, this cave is an important archeological site documented in other works (Elliott \& Reddell, 1985). Despite the protection that the cave receives, the population of A. texanus inside the cave must be very small, since only 6 specimens have been collected from 1984 to 2015, which suggests that the population is threatened.

The same situation is found in the type locality of A. tenebris, which is a cave in the middle of the city of Valle de Bravo and despite being a relatively small cave, the people go into the cave to vandalize it, and deposit garbage inside, disturbing the original microhabitats. This vandalism appears to be affecting directly the populations of schizomids since attempts to collect more material in May 2015 were totally unsuccessful.

The cave Las Grutas de Quintero in Ciudad Mante in the past was a very touristic site; however, due to some government mismanagement it was transformed into a mine for the extraction of phosphorite and guano. The introduction of heavy machinery has disturbed severely the original aspect and the environment of the cave. Unfortunately, we have been unable to visit the cave lately to assess the status of the protoschizomid population due to the lack of personal security in the area.

In June 2015 we visited the type locality of A. stygius in Hidalgo with the intention of collecting the unknown male; however, the entrance pit of the cave was completely blocked by a large pine tree log carried in by flash floods, and subsequently smaller debris carried by the stream that enters the cave, and garbage that people of the nearest town throw inside the cave created a massive plug; therefore, our attempt to collect the species were completely unsuccessful since we were not able to enter the cave.

Unfortunately, in Mexico there is no legal protection or management of caves or cave resources. The only "management" related with caves is handled by the owners of the caves when they use them for tourism, but that protection involves only infrastructure for accessibility to the caves and does not involve any kind of legislation or protection related with fauna or life inside them. Another example is the case where the INAH (Instituto Nacionald e Antropología e Historia) protects the caves only if some archeological artifacts are found inside, or if certain animal species such as bats are present; however, they do not protect any other caves or the special environments that the caves represent. For these reasons, regulation of the use of caves is urgently needed to protect them, as well as a strong educational campaign to teach local inhabitants the importance of ecological conservation of these environments.

\section{Acknowledgments}

For the loan of specimens we are grateful to Lorenzo Prendini, American Museum of Natural History, New York, and to James R. Reddell, Texas Natural History Collections/Texas Memorial Museum, Austin. Thanks to P. Sprouse, A. Scott, B. Hutchins, W. Elliott, L. Bemet, P. Paquin, M. Sanders, K. O'Connor, D. Barrales, J. Mendoza, E. Miranda and A. Valdez for their collecting efforts in the caves. Special thanks to Mr. Ben Hutchins, biologist for the Texas Parks and Wildlife Department for permission to search Seminole Cave in 2015 for additional specimens, and for participating along with Peter Sprouse and Ann Scott in searching the cave; and to the 3 of them for donating those paratypes to the Colección Nacional de Arácnidos, IBUNAM. The first author thanks the Consejo Nacional de Ciencia y Tecnología and the Posgrado en Ciencias Biológicas, Instituto de Biología, UNAM for financial support. Specimens in Mexico were collected under the scientific collector permit FAUT-175 granted by Semarnat, Mexico, to Oscar F. Francke.

\section{References}

Cokendolpher, J. C., \& Reddell, J. R. (1992). Revision of the Protoschizomidae (Arachnida: Schizomida) with notes on the phylogeny of the order. Texas Memorial Museum, Speleological Monographs, 3, 31-74.

Elliott, W. R., \& Reddell, J. R. (1985). The biology of Seminole Sink. In S. A. Turpin (Ed.), Excavation of a vertical shaft tomb, Val Verde County, Texas. Texas Archeological Survey, Research Report, 93, 211-216.

Galán, C., \& Herrera, F. F. (1998). Fauna cavernícola: ambiente, especiación y evolución. Boletín de la Sociedad Venezolana de Espeleología, 32, 13-43.

Harvey, M. S. (1992). The Schizomida (Chelicerata) of Australia. Invertebrate Taxonomy, 6, 77-129.

Krantz, G. W., \& Walter, D. E. (2009). Collecting, rearing, and preparing specimens. In G. W. Krantz, \& D. E. Walter (Eds.), A manual of Acarology, 3rd Ed. (pp. 83-96). Lubbock, TX: Texas Tech University Press.

Lawrence, R. F. (1969). The trichoid structures on the chelicerae of the shorttailed whip-scorpions (Schizomida: Arachnida). Transactions of the Royal Society of South Africa, 38, 123-132.

Monjaraz-Ruedas, R. (2013). A new species of Protoschizomus (Schizomida: Protoschizomidae) from a cave in Guerrero, Mexico. Journal of Arachnology, 41, 420-424.

Monjaraz-Ruedas, R., \& Francke, O. F. (2015). Taxonomic revision of the genus Mayazomus Reddell and Cokendolpher, 1995 (Schizomida: Hubbardiidae), with description of 5 new species from Chiapas, Mexico. Zootaxa, 3915, 451-490.

Montaño-Moreno, H., \& Francke, O. F. (2009). A new species of Agastoschizomus (Schizomida: Protoschizomidae) from Guerrero, Mexico. Texas Memorial Museum, Speleological Monographs, Studies on the Cave and Endogean Fauna of North America, 5, 33-36.

Reddell, J. R., \& Cokendolpher, J. C. (1995). Catalogue, bibliography, and generic revision of the order Schizomida (Arachnida). Texas Memorial Museum, Speleological Monographs, 4, 1-170. 